Original Article \title{
Absenteeism in the nursing team in surgical-clinical units of
a philanthropic hospital*
}

\author{
Ausências na equipe de enfermagem em unidades de clinica médico-cirúrgica de um hospital \\ filantrópico \\ Ausentismo en el equipo de enfermería de unidades de clínica médico-quirúrgica de un hospital \\ filantrópico
}

\section{Danielle Fabiana Cucoloํ, Márcia Galan Perroca ${ }^{2}$}

\begin{abstract}
Objective: Identify the rate of absenteeism in the nursing team in surgical-clinical units of a philanthropic hospital in the interior of the state of São Paulo, and determine the technical safety index for each professional category. Methods: Data were collected from documents of the Nursing and Personnel Departments, covering the year 2006, using the equations proposed by Gaidzinski. Results: The percentage of planned absences (days off, holidays and vacations) corresponded, respectively, to $17 \%, 3.1 \%$ and $9 \%$. Maternity leaves were identified as the main reason for unplanned absences for the nursing workers, followed by medical leaves. The technical safety index varied from $32 \%$ to $47 \%$ for nurses and from $35 \%$ to $40 \%$ for nursing auxiliaries and nursing technicians. Conclusion: The identification of the safety index for covering absences provides nurses with tools for planning nursing human resources quanti-qualitatively.
\end{abstract}

Keywords: Nursing staff; Nursing, team; Absenteeism; Hospitals, voluntary

\section{RESUMO}

Objetivo: Identificar o percentual de absenteísmo na equipe de enfermagem em unidades de clínica médico-cirúrgica de um hospital filantrópico do interior do Estado de São Paulo e determinar o índice de segurança técnico para cada categoria profissional. Métodos: Os dados foram coletados de documentos dos Departamentos de Enfermagem e de Pessoal, referentes ao ano de 2006, utilizando-se as equações propostas por Gaidzinski. Resultados: Os percentuais de ausências previstas (folgas, feriados e férias) corresponderam, respectivamente, a $17 \%, 3,1 \%$ e $9 \%$. A licença maternidade foi identificada como principal motivo de ausência não prevista dos trabalhadores de enfermagem, seguida pela licença médica. O índice de segurança técnico apresentou variação de 32\% a 47\%, para os enfermeiros, e de 35\% a $40 \%$ para os auxiliares e técnicos de enfermagem. Conclusão: A identificação do índice de cobertura de ausências instrumentaliza os enfermeiros no planejamento quantiqualitativo de recursos humanos em enfermagem.

Descritores: Recursos humanos de enfermagem; Equipe de enfermagem; Absenteísmo; Hospitais filantrópicos

\section{RESUMEN}

Objetivo: Identificar el porcentaje de ausentismo en el equipo de enfermería que trabaja en unidades de clínica médico-quirúrgica de un hospital filantrópico del interior del Estado de Sao Paulo y determinar el índice de seguridad técnica para cada categoría profesional. Métodos: Los datos fueron recolectados de documentos de los Departamentos de Enfermería y de Personal, referentes al año 2006, haciendo uso de las ecuaciones propuestas por Gaidzinski. Resultados: Los porcentajes de ausencias previstas (descansos, feriados y vacaciones) correspondieron, respectivamente, al 17\%, 3,1\% y 9\%. La licencia por maternidad fue identificada como el principal motivo de ausencia no prevista de los trabajadores de enfermería, seguida por la licencia médica. El índice de seguridad técnica presentó una variación del 32\% a 47\%, para los enfermeros, y del 35\% a 40\% para los auxiliares y técnicos de enfermería. Conclusión: La identificación del índice de cobertura de ausencias instrumentaliza a los enfermeros en la planificación cuanticualitativa de recursos humanos en enfermería.

Descriptores: Personal de enfermería; Grupo de enfermería; Absentismo; Hospitales filantrópicos

\footnotetext{
* Study developed at Irmandade Santa Casa de Misericórdia - São José do Rio Preto - (SP), Brazil.

${ }^{1}$ Graduate student in Healthcare Sciences - Faculdade de Medicina de São José do Rio Preto - FAMERP - São José do Rio Preto (SP), Brazil.

${ }^{2}$ Ph.D, Professor in the Specialized Nursing Course at Faculdade de Medicina de São José do Rio Preto - FAMERP - São José do Rio Preto (SP), Brazil.
} 


\section{INTRODUCTION}

Absenteeism is understood as the absence of the employee from the workplace ${ }^{(1-3)}$, covering several causes related to unplanned absences: non-attendance (justified or unjustified), leaves (medical, maternity, paternity, mourning) and suspensions ${ }^{(4)}$. Planned absences within a legal work period are considered expected absences, covering vacations, leaves (paid weekly days off), and holidays that do not coincide with Sundays ${ }^{(4)}$. The sum of planned and unplanned absences constitutes the technical safety index (TSI). As such, the TSI represents the amount of professionals to be added to the total number in each category to cover these days of absence, constituting one of the variables in the personnel dimensioning $\operatorname{method}^{(1,4-6)}$.

The variable absence in the nursing team, regarding days off, vacations and leaves, was introduced in the late 1950s by the American Hospital Association to calculate personnel. At the time, an arbitrary addition of $20 \%$ was recommended, a value to be indistinctly used in all institutions ${ }^{(4)}$. Since then, the determination of an index to cover absences, according to each institution's reality, has been a complex aspect attributed to the methods for personnel dimensioning, since the nursing team is a representative share of human resources in healthcare institutions in quantitative terms ${ }^{(1,7)}$. The insufficiency of nursing professionals to care for the patients' needs can jeopardize healthcare quality and user safety due to work overload. Therefore, hospital stays can be lengthened, incurring in higher costs, and also exposing the nursing team and the company to legal and ethical matters ${ }^{(6-9)}$.

Due to the lack of official guiding parameters for personnel dimensioning, the Federal Nursing Council Conselho Federal de Enfermagem (COFEN) published Resolution \# 186/96 in 1996 ${ }^{(10)}$, which established a 30\%index to cover planned and unplanned absences. When seven weekdays were considered in calculations, the paid weekly days off were already covered, which caused an overestimation of the percentages for covering absences $^{(1,4,8)}$. In 2004, this resolution was substituted by COFEN Resolution \#293 ${ }^{(11)}$, which recommends a TSI not lower than $15 \%$. In 1988, Gaidzinski ${ }^{(4)}$ proposed an equation for nursing personnel dimensioning considering three variables: workload, TSI and effective working time. The author also recommended that each institution should establish absenteeism percentages compatible with its own reality.

In this context, the evaluation of the amount of nursing personnel in hospital units represents an instrument that supports the nurse to plan and distribute the human resources available, guaranteeing better security and quality for the healthcare provided. In view of the importance of knowing the absenteeism percentage in the nursing team to adequate the number of employees to the institutional reality, and also to propose intervention measures, this study had the following objectives:

- Identify the rate of absenteeism in the nursing team in surgical-clinical units of a philanthropic hospital in the interior of the state of São Paulo.

- Determine the TSI for each professional category.

\section{METHODS}

This is a descriptive study with a quantitative approach, performed in four medical-surgical clinical hospitalization units in a large philanthropic hospital in the state of São Paulo, Brazil. Data were retrospectively collected from January to December, 2006, after being approved by the Review Board (Protocol \#1883/2007). The professional categories observed were: Nurses, nursing technicians and nursing auxiliaries. Since the activities performed by nursing technicians and auxiliaries do not differ at the field study institution, these categories were grouped.

Documents from the Personnel Department (absenteeism records) and the Nursing Department (Monthly shift distribution) were used to obtain the amount of planned and unplanned absences in the nursing personnel. For calculation purposes, employees admitted up to the $5^{\text {th }}$ day and who worked up to the $25^{\text {th }}$ day of the month were included, considering a six-hour period for absences or missed days ${ }^{(4)}$.

The following equations were used to calculate the percentage of planned absences ${ }^{(4)}$ :

1) Weekly days off (paid days off):

$\mathrm{E} \%=\left(\frac{\mathrm{e}}{\mathrm{d}-\mathrm{e}}\right) \cdot 100$

Where:

$\mathrm{e}=$ amount of days off per week, resulting from the weekly workload determined by the institution;

$\mathrm{d}=$ number of days the institution works in a week.

2) Holidays (number of holidays that do not coincide with Sundays):

$\mathrm{F} \%=\left(\frac{\mathrm{f}}{\mathrm{D}-\mathrm{f}}\right) \cdot 100$

Where:

$\mathrm{f}=$ Yearly average of holidays that do not coincide with Sundays granted by the institution;

$\mathrm{D}=$ Days of the year.

3) Vacations (30 days for each worker, per year of work):

$\mathrm{V} \%=\left(\frac{\mathrm{v}}{\mathrm{D}-\mathrm{v}}\right) \cdot 100$

Where:

$\mathrm{v}=$ Average number of yearly vacation days;

$\mathrm{D}=$ Days of the year.

The following equation was used to calculate the 
percentage of unplanned absences, corresponding to the sum of absences due to missed days, leaves and suspensions $^{(4)}$ :

$\mathrm{A}_{\mathrm{k}} \%=\left(\frac{\mathrm{a}_{k}-\mathrm{a}_{\mathrm{k}}}{\mathrm{D}-\mathrm{a}_{\mathrm{k}}} \cdot 100\right.$

Where:

$\mathrm{K}=$ index indicating the professional category;

$\mathrm{a}_{\mathrm{k}}=$ yearly average of unplanned absence days in professional category $\mathrm{k}$;

$\mathrm{D}=$ Days of the year.

Next, the TSI was determined, corresponding to the percentage added in the personnel calculation formula, aiming to cover the need for professionals due to the specific characteristics of the institution, using the following equation ${ }^{(4)}$ :

$$
\text { TSI }=\left[\left(1+\frac{e}{d-e}\right) \cdot\left(1+\frac{v_{k}-}{D-v_{k}}\right) \cdot\left(1+\frac{f}{D-f}\right) \cdot\left(1+\frac{a_{k}-}{D-a_{K}}\right)\right]
$$

The data obtained were organized in spreadsheets with Microsoft Excel, and are presented as frequencies and percentages.

\section{RESULTS}

The analysis of the monthly shift distribution and documents from the Personnel Department regarding absenteeism in the nursing team showed the reality of the studied units, with the description of the results as follows.

Absences planned due to weekly days off:

At the institution studied, the nursing team is hired for a 36-hour work week, in daily 6-hour shifts with one day off per week, or 12-hour night shifts with a 36-hour rest interval.
Placing these figures in the equation results in:

$$
\mathrm{E} \%=\left(\frac{1}{7-1}\right) \cdot 100=17 \%
$$

This figure represents the coverage percentage of the nursing team's weekly days off per paid day off.

\section{Absences planned due to holidays:}

Along the year, holidays are not applicable to the whole country, according to federal, state and city laws. The latter two also differ according to state and city ${ }^{(4)}$.

Nursing services working in a system of rotating shifts, without a fixed day off, are entitled to the number of days off corresponding to the number of holidays that do not coincide with Sundays ${ }^{(4)}$.

In the studied period, 11 holidays that did not coincide with Sundays were granted by the institution. Therefore:

$$
\mathrm{F} \%=\left(\frac{11}{365-11}\right) \cdot 100=\mathbf{3 . 1} \%
$$

\section{Absences planned due to vacations:}

According to law, workers are entitled to a yearly $30-$ day period off-work. Applying that to the equation:

$$
\mathrm{V} \%=\left(\frac{30}{365-30}\right) \cdot 100=8.9 \%=\mathbf{9} \%
$$

\section{Unplanned absences}

Research about the total number of unplanned absences per professional category, as well as the average amount of nursing workers in each hospitalization unit allowed for the identification of the yearly average absenteeism of nurses, nursing auxiliaries and nursing technicians (Table 1). In this table, the variation in the average number of nurses - 4.3 to 4.7 - and among

Table 1 - Number of beds, average number of nursing professionals and average yearly number of absences, according to professional category, at hospitalization units of a philanthropic hospital - 2006

\begin{tabular}{cccccccc}
\hline \multirow{2}{*}{$\begin{array}{l}\text { Hospitalization } \\
\text { Unit }\end{array}$} & $\begin{array}{c}\text { No. of } \\
\text { beds }\end{array}$ & \multicolumn{3}{c}{$\begin{array}{c}\text { Average yearly number of nursing } \\
\text { professionals }\end{array}$} & \multicolumn{3}{c}{ Average yearly number of absences } \\
\cline { 3 - 8 } & & Nurse & $\begin{array}{c}\text { Technician/ } \\
\text { Auxiliary }\end{array}$ & Total & Nurse & $\begin{array}{c}\text { Technician/ } \\
\text { Auxiliary }\end{array}$ & Total \\
\hline I & 22 & 4.6 & 12.7 & 17.3 & 37.5 & 14.4 & 51.9 \\
II & 30 & 4.7 & 16.3 & 21.0 & 37.0 & 23.1 & 60.1 \\
IV & 24 & 4.3 & 14.2 & 18.5 & 23.6 & 10.0 & 33.6 \\
VI & 41 & 4.3 & 20.4 & 24.7 & 2.3 & 14.7 & 17.0 \\
\hline Total & $\mathbf{1 1 7}$ & $\mathbf{1 7 . 9}$ & $\mathbf{6 3 . 6}$ & $\mathbf{8 1 . 5}$ & $\mathbf{1 0 0 . 4}$ & $\mathbf{6 2 . 2}$ & $\mathbf{1 6 2 . 6}$ \\
\hline
\end{tabular}


nursing technicians and auxiliaries -12.7 to 20.4 is observed.

Data in Table 2 show that the highest unplanned absenteeism percentages in the category nurses were 11.5\% (unit I) and $11.3 \%$ (unit II). Regarding the nursing technician and auxiliaries, the highest percentage was $6.7 \%$ (unit II).

Maternity leaves $(6.4 \%$ to $8.0 \%)$ and medical leaves $(0.5 \%$ to $2.5 \%)$ represent the highest percentages of unplanned absences for the category nurses (Table 3). For nursing auxiliaries and technicians, maternity leaves $-1.7 \%$ to $3.5 \%$ - and medical leaves were equally found, added to the Social Security (INSS) leaves $-0.8 \%$ to $1.3 \%$ (Table 4).

The TSI calculations for each hospitalization unit showed an increase from $32 \%$ to $47 \%$ for the category nurses and from 35 to $40 \%$ for the categories nursing auxiliaries and nursing technicians (Table 5).

Table 2 - Yearly percentage of unplanned absences in the nursing team of surgical-medical clinical units, per professional category - 2006

\begin{tabular}{lrrrr}
\hline \multirow{2}{*}{ Professional Category } & \multicolumn{4}{c}{ Hospitalization Units } \\
\cline { 2 - 5 } & I & II & IV & VI \\
\hline Nurse & 11.5 & 11.3 & 6.9 & 0.6 \\
Technician/Auxiliary & 4.1 & 6.7 & 2.8 & 4.2 \\
\hline General percentage & 6.0 & 7.7 & 3.7 & 3.5 \\
\hline
\end{tabular}

Table 3 - Distribution of the percentage of unplanned absences in the category nurses, according to surgical-medical clinical units and type of unplanned absences - 2006

\begin{tabular}{lrccc}
\hline \multirow{2}{*}{$\begin{array}{l}\text { Types of unplanned } \\
\text { absences - nurse }\end{array}$} & \multicolumn{4}{l}{ Hospitalization Units } \\
\cline { 2 - 5 } & \multicolumn{1}{c}{ I } & II & IV & VI \\
\hline Missed days & 1.0 & 1.0 & - & - \\
Medical leaves & 2.5 & 2.5 & 0.5 & 0.6 \\
Maternity leaves & 8.0 & 7.6 & 6.4 & - \\
Wedding leaves & - & 0.2 & - & - \\
\hline Total & 11.5 & 11.3 & 6.9 & 0.6 \\
\hline
\end{tabular}

Table 4 - Distribution of the percentage of unplanned absences in the category nursing technicians and auxiliaries, according to surgical-medical clinical units and type of unplanned absences - 2006

\begin{tabular}{lcccc}
\hline \multirow{2}{*}{$\begin{array}{l}\text { Types of unplanned } \\
\text { absences - nursing } \\
\text { technicians and auxiliaries }\end{array}$} & \multicolumn{4}{l}{ Hospitalization Units } \\
\cline { 2 - 5 } & I & II & IV & VI \\
\hline Missed days & 0.5 & 0.7 & 0.3 & 0.3 \\
Medical leaves & 0.9 & 1.6 & 1.1 & 0.6 \\
Maternity leaves & 2.7 & 3.5 & - & 1.7 \\
Accident leaves & - & - & - & 0.2 \\
Social security leaves & - & 0.8 & 1.2 & 1.3 \\
Suspensions & - & - & 0.1 & - \\
\hline Total & 4.1 & 6.6 & 2.7 & 4.1 \\
\hline
\end{tabular}

Table 5 - percentage of personnel addition to cover planned and unplanned absences in the nursing team at the surgical-medical clinical units according to professional category - 2006

\begin{tabular}{lcccc}
\hline \multirow{2}{*}{ Professional Category } & \multicolumn{4}{c}{ Hospitalization Units } \\
\cline { 2 - 5 } & I & II & IV & VI \\
\hline Nurse & $47 \%$ & $46 \%$ & $41 \%$ & $32 \%$ \\
Technician/Auxiliary & $37 \%$ & $40 \%$ & $35 \%$ & $37 \%$ \\
\hline
\end{tabular}

\section{DISCUSSION}

By observing the quantity of professionals currently assigned to the units studied, it can be verified that the average number of nurses was not altered in relation to the number of beds in these units. However, the number of nursing technicians and auxiliaries increased as the unit made more beds available. In the percentage distribution of the total amount of professionals, the proportion of nursing technicians and auxiliaries varied from $73.4 \%$ to $82.6 \%$, with an increasing percentage following an increased availability of beds. However, the participation of the nurse in the team has decreased significantly, from $26.6 \%$ to $17.4 \%$, as the units deliver care to more patients. Therefore, it can be noticed that the intuitive and deterministic method, based on the proportional relation between the number of employees for the number of beds available has been used in several hospitals to determine the dimensions of the nursing personnel, leveling the patients' care needs ${ }^{(4-5,9)}$.

According to COFEN resolution \#293/2004 ${ }^{(11)}$, the percentage distribution of the professionals should obey the proportion of $33 \%$ to $37 \%$ nurses and $63 \%$ to $67 \%$ nursing technicians and auxiliaries. However, the percentage of nurses in the team is still below expected standards. The low number of nurses may jeopardize the supervision of healthcare, causing deficiencies in healthcare organization and quality. However, in several healthcare services, the recommended proportion is unfeasible in practical terms, due to the impact of the adjustment policies, which impose limits on public spending ${ }^{(5)}$. In the studied institutions, the ratio between the nurses and the nursing technicians and auxiliaries shows lower values than those recommended by COFEN, a reality that was also evidenced by other authors ${ }^{(5,9)}$.

Higher percentages for unplanned absenteeism were found for the category nurses in three hospitalization units investigated. These findings can be explained by the low average number of these professionals in the composition of the nursing team at the institution (varying from 17.4\% to $26.6 \%$ ), which could have overrated the calculation of absences. In a study performed in surgical-medical clinical units of a university hospital in the state of São Paulo ${ }^{(5)}$, the percentage of unplanned absences among all units 
varied from $0.9 \%$ to $12.4 \%$ for nurses and $0.5 \%$ to $11.6 \%$ for nursing technicians and auxiliaries. At one of the units, $46.3 \%$ was found for unplanned absences of nurses, considered atypical by the author due to the small sample size. Other research findings presented $6.6 \%$ for nurses and $9.8 \%$ for nursing technicians and auxiliaries at the surgical and medical units ${ }^{(1)}$ and a general percentage of $8.2 \%$ for nurses and $9.3 \%$ for nursing technicians and auxiliaries at hospitalization units of a university hospital in the state of Paraná(9).

For the category nurses, maternity leave was the type of unplanned absence with the highest percentage in three out of four units studied $(6.4 \%$ to $8.0 \%)$, followed by medical leaves ( 0.5 to $2.5 \%$ ) and missed days. Studies performed at university hospitals have also identified maternity leaves as the highest percentage values for unplanned absences - from $2.3 \%$ to $3.8 \%{ }^{(1)}$ and from $5.3 \%$ to $12.1 \%{ }^{(5)}$.

As for nursing technicians and auxiliaries, maternity leaves were also the type of unplanned absence with the highest percentage values $(1.7 \%$ to $3.5 \%)$, followed by medical $(0.6 \%$ to $1.6 \%)$ and social security leaves $(0.8 \%$ to $1.3 \%)$. An investigation performed at a university hospital in western Paraná( ${ }^{(9)}$ showed percentages from $1.5 \%$ to $2.7 \%$ for maternity leaves and $3.2 \%$ to $8.5 \%$ for medical leaves. Also, 3.4\% for maternity leaves, $0.9 \%$ to $1.8 \%$ for medical leaves and between $1.0 \%$ and $4.0 \%$ for social security leaves were found in literature ${ }^{(1)}$. Another research found $1.4 \%$ and $3.8 \%$ for maternity leaves, $0.07 \%$ to $2.5 \%$ for medical leaves and from $0.2 \%$ to $8.5 \%$ for INSS* social security leaves ${ }^{(5)}$.

These findings corroborate the reality presented in this research, except for the medical leaves found in one study $(3.2 \% \text { to } 8.5 \%)^{(9)}$. Regarding nursing technicians and auxiliaries, the absences due to social security leaves are a source of concern, since they represent the largest group of nursing professionals and, most of the times, it is not possible to predict when these professionals will return to work, jeopardizing the workload of the other employees at the institution ${ }^{(5)}$.

In nursing, the marks of ideological contents that attribute an innate ability for care to women are still present. Many of these women, performing their work duties during the reproductive stage of their lives, are known to possibly become absent from work in different phases of the pregnancy-puerperal cycle, or to care for their children. Added to these characteristics, the women perform, besides their daily work shift, a wide range of tasks: social roles of wife, housewife and mother, implying a mental and physical overload, concerns and lack of rest, which can trigger mental or physical diseases ${ }^{(2)}$.

* INSS - Instituto Nacional do Seguro Social
The causes of absenteeism, i.e. unplanned absences at work, are multiple and not always related to the worker, but also to the company. Nursing work is performed in long shifts and in turns, with rotation and multiplicity of tasks, marked by repetition and monotony, physical effort, ergonomically-unfeasible positions, anxiety, stress and management control, which can also trigger diseases and accidents ${ }^{(3)}$. The insufficient number of human resources can aggravate this situation even more, increasing the percentage of unplanned absences in the nursing sector, resulting in disorganization, dissatisfaction and overload of the professionals and, consequently, reducing the quality of the healthcare provided ${ }^{(3)}$.

However, opposed to what is usually believed, unplanned absences do not comprise the highest percentage for covering absences in the nursing team. It is important to highlight that planned absences (days off, vacations and holidays) exert the strongest impact on the TSI determination.

The percentage found for covering absences (TSI) for the category of nurses was from $32 \%$ to $47 \%$, approximating $39 \%$ to $43 \%{ }^{(9)}, 36 \%$ to $42 \%{ }^{(1)}$ in some studies; however, this remained below other percentages found, from $55 \%$ to $78 \%{ }^{(5)}$. Also, in the category of nursing technicians and auxiliaries, the findings of this research $(35 \%$ to $40 \%)$ showed to be similar to others, developed in university hospitals, from $38 \%$ to $46 \%{ }^{(9)}$, between $37 \%$ and $46 \%{ }^{(1)}$ and lower than one other study $(59 \% \text { to } 79.3 \%)^{(5)}$.

The TSI recommended by the Federal Nursing Council-COFEN (11) is not inferior to $15 \%$, with $8.33 \%$ to cover vacations and the remaining $6.67 \%$ (arbitrary value) to cover the index of absenteeism. Therefore, even using the recommended TSI, the percentage of absences due to days off and holidays needs to be verified for additions to personnel, since the simple coverage of days off, vacations and holidays represented nearly $29 \%$ altogether. Therefore, it is recommended that methods of individual and systematized analysis be developed, expressing percentage values for absence coverage, according to the reality of each institution, making it possible to adequate the group of nursing professionals and to guarantee better quality in the work environment and healthcare provided ${ }^{(5)}$.

\section{CONCLUSION}

The early identification of the absence coverage index in the categories of the nursing team offers support to plan human resources of this area in quantitative and qualitative terms. This is considered an important finding since it is one of the variables used to (re)dimension the group of professionals according to the reality of each service. 


\section{REFERENCES}

1. Fugulin FMT, Gaidzinski RR, Kurcgant P. Ausências previstas e não previstas da equipe de enfermagem das unidades de internação do HU-USP. Rev Esc Enferm USP. 2003; 37(4):109-17.

2. Nascimento GM. Estudo do absenteísmo dos trabalhadores de enfermagem em uma unidade básica e distrital de saúde do município de Ribeirão Preto - SP [dissertação ]. Ribeirão Preto: Escola de Enfermagem de Ribeirão Preto da Universidade de São Paulo; 2003.

3. Silva DMPP, Marziale MHP. Absenteísmo de trabalhadores de enfermagem em um hospital universitário. Rev Latinoam Enferm. 2000; 8(5):44-51.

4. Gaidzinski RR. Dimensionamento de pessoal de enfermagem em instituições hospitalares [tese ]. São Paulo: Escola de Enfermagem da Universidade de São Paulo; 1998.

5. Laus AM. Dimensionamento de pessoal de enfermagem para unidades de internação médicas e cirúrgicas no Hospital das Clínicas da Faculdade de Medicina de Ribeirão Preto USP [tese ]. Ribeirão Preto: Escola de Enfermagem de Ribeirão Preto da Universidade de São Paulo; 2003.

6. Rogenski KE. Tempo de assistência de enfermagem: identificação e análise em instituição hospitalar de ensino [dissertação ]. São Paulo: Escola de Enfermagem da
Universidade de São Paulo; 2006.

7. Chenso MZB, Haddad MCL, Sêcco IAO, Dorigão AM, Nishiyama MN. Cálculo de pessoal de enfermagem em Hospital Universitário do Paraná: uma proposta de adequação. Semina Cienc Biol Saude. 2004; 25:81-92.

8. Antunes AV, Costa MN. Dimensionamento de pessoal de enfermagem em um hospital universitário. Rev Latinoam Enferm. 2003; 11(6):832-9.

9. Nicola AL. Dimensionamento de pessoal de enfermagem no hospital universitário do oeste do Paraná [tese]. Ribeirão Preto: Escola de Enfermagem de Ribeirão Preto da Universidade de São Paulo; 2005.

10. Conselho Federal de Enfermagem. Resolução COFEN n ${ }^{\circ}$ 189/96. Estabelece parâmetros para dimensionamento do quadro de profissionais de enfermagem nas instituições de saúde. In: Conselho Regional de Enfermagem de São Paulo. Documentos básicos de enfermagem: enfermeiros, técnicos, auxiliares. São Paulo: COREN/SP; 2001. p. 144-51.

11. Brasil. Conselho Federal de Enfermagem. Resolução no 293 , de 21 de Setembro de 2004 [ Internet]. Brasília (DF): Conselho Federal de Enfermagem; 2004 [citado 2007 Nov 30]. Disponível em: URL: www.portalcofen.gov.br/2007/ materias.asp?ArticleID $=7121$ \&sectionID $=34$ 